Rahman, et al/Jurnal Ekonomi Syariah Teori dan Terapan Vol. 6 No. 12 Desember 2019: 2498-2511; KESEJAHTERAAN DALAM PERSPEKTIF MAQASHID SYARIAH PADA KARYAWAN BADAN AMIL ZAKAT DAN LEMBAGA AMIL ZAKAT DI KOTA SURABAYA

\title{
KESEJAHTERAAN DALAM PERSPEKTIF MAQASHID SYARIAH PADA KARYAWAN BADAN AMIL ZAKAT DAN LEMBAGA AMIL ZAKAT DI KOTA SURABAYA'
}

\author{
Annisa Dinar Rahman \\ Departemen Ekonomi Syariah- Fakultas Ekonomi dan Bisnis- Universitas Airlangga \\ Email: dinarrahman04@gmail.com \\ Siti Inayatul Faizah \\ Departemen Ekonomi Syariah- Fakultas Ekonomi dan Bisnis- Universitas Airlangga \\ Email: naya_viencha@yahoo.co.id
}

\begin{abstract}
:
This study aims to determine the welfare of employees at the Amil Zakat Agency and the Amil Zakat Institution in Surabaya if it is reviewed through the perspective of maqashid sharia. This study uses a qualitative case study approach with descriptive analysis techniques through interviews, documents, and direct observation. The scope of this research focuses on employees of the Amil Zakat Agency and the Amil Zakat Institution. The results of this study are economic conditions in terms of income received by employees of the Amil Zakat Agency and the Amil Zakat Institution are sufficient. This economic situation can be seen from the amount of income received per month, fulfillment of needs, and assets owned. Fulfillment of welfare for employees at the Amil Zakat Agency and the Amil Zakat Institution can be said to be prosperous. This welfare can be seen from the maqashid sharia indicator used in this study, which is maintaining religion, nurturing the soul, nurturing the logics, raising offspring, and maintaining wealth, both the Amil Zakat Agency and the Amil Zakat Institution have received and benefited from the facilities provided by the institution, such as the existence of health benefits (BPJS).
\end{abstract}

Keywords: Employee welfare, Maqashid Syariah, Amil Zakat Agency, Amil Zakat Institution

\section{PENDAHULUAN}

Kesejahteraan menurut Islam terbagi menjadi kesejahteraan materi dan non materi. Kesejahteraan materi meliputi jumlah materi yang dimiliki, pendapatan yang diterima, dan lainnya yang dapat dihitung secara materil. Kesejahteraan non materi adalah kesejahteraan yang tidak berbentuk barang atau sejenisnya, contohnya kesehatan, keturunan yang sholeh dan sholehah, dan lain sebagainya. Pendapat Umar Chapra dalam menggambarkan tentang kesejahteraan ekonomi dalam Islam yaitu beliau menjelaskan bahwa terdapat hubungan yang erat antara syariat Islam dengan kemaslahatan (Chapra, 2001: 102).

Al-Qur'an telah menjelaskan mengenai indikator kesejahteraan yang terdapat dalam Surat Quraisy ayat 3-4 yang berbunyi: Falya'buduu rabba hadzaal bait(i). al-ladzii ath'amahum min juu'iu(n) wa-aamanahum min khauf(in).

Artinya : "Maka hendaklah mereka menyembah Tuhan (pemilik) rumah ini (Ka'bah). yang telah memberikan makanan kepada mereka untuk menghilangkan lapar dan mengamankan mereka dari rasa takut." (Depag RI dan Terjemahannya, 2000).

\footnotetext{
${ }^{1}$ Jurnal ini merupakan bagian dari skripsi dari Annisa Dinar Rahman, NIM: 04141 1431030, yang diuji pada 17 Juli 2019.
} 
Rahman, et al/Jurnal Ekonomi Syariah Teori dan Terapan Vol. 6 No. 12 Desember 2019: 2498-2511; KESEJAHTERAAN DALAM PERSPEKTIF MAQASHID SYARIAH PADA KARYAWAN BADAN AMIL ZAKAT DAN LEMBAGA AMIL ZAKAT DI KOTA SURABAYA

Berdasarkan ayat tersebut maka dapat dilihat bahwa terpenuhinya kesejahteraan di bidang rohani diperlukan agar manusia mengalami kebahagiaan. Selanjutnya terpenuhinya kebutuhan konsumsi agar dapat bertahan hidup sebagaimana dapat dilihat dalam kalimat tersebut. Terakhir, manusia membutuhkan rasa aman dan terlindungi. Ketiga hal tersebut menjadi sumber utama yang ingin dicapai masyarakat sehingga apabila terpenuhi maka masyarakat telah sejahtera hidupnya. (J. Filasufah, 2011).

Salah satu usaha untuk memenuhi kesejahteraan di bidang ekonomi adalah dengan bekerja, baik dengan membuka lapangan pekerjaan atau menjadi tenaga kerja bagi orang lain. Penduduk usia kerja adalah penduduk berumur 15 tahun lebih, menurut data Badan Pusat Statistik hingga Agustus 2018 jumlah penduduk usia kerja di Indonesia mencapai 194,78 juta orang. Penduduk usia kerja sendiri terbagi menjadi dua yaitu angkatan kerja dan bukan angkatan kerja (Badan Pusat Statistik, 2018). Berikut ini data struktur ketenagakerjaan di Indonesia dari Badan Pusat Statistik :

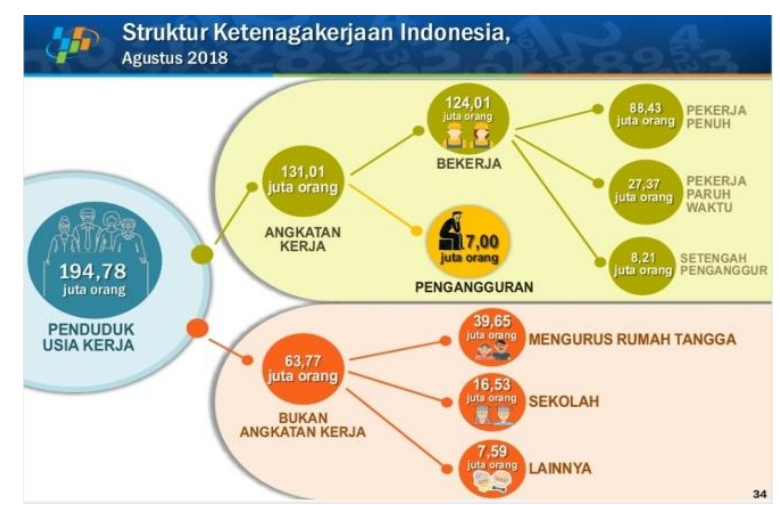

Gambar 1.

\section{Struktur Ketenagakerjaan Indonesia Bulan} Agustus 2018 (BPS, 2018)

Berdasarkan gambar tersebut, dapat diketahui bahwa penduduk usia kerja mencapai 194,78 juta orang yang terbagi dalam dua kategori yaitu angkatan kerja dan bukan angkatan kerja. Jumlah angkatan kerja di Indonesia mencapai 131,01 juta orang, sedangkan bukan angkatan kerja mencapai 63,77 juta orang. Meskipun termasuk dalam angkatan kerja namun tidak semuanya memiliki pekerjaan, dari total angkatan kerja yang memiliki pekerjaan sejumlah 124,01 juta orang sisanya sebesar 7,00 juta orang sebagai pengangguran.

Dalam pasal 30 Undang-Undang Nomor 23 Tahun 2011 tentang Pengelolaan Zakat menyebutkan bahwa dalam melaksanakan tugasnya BAZNAS dibiayai oleh APBN. Selain itu BAZ dan LAZ yang bertugas mengelola zakat juga berwenang mengelola $1 / 8$ dari jumlah dana untuk operasional karyawan karena posisinya sebagai amil. Pekerja yang bekerja di dalam lembaga tersebut tidak hanya terbatas pada pengelola, namun juga ada pengurus dan karyawan. Pada dasarnya bekerja dalam lembaga tersebut tidak mengharapkan keuntungan yang besar atau honor yang tinggi. Namun, pemenuhan kebutuhan hidup juga perlu diperhatikan, sehingga kelvarga dari karyawan BAZ dan LAZ dapat terpenuhi kebutuhannya.

Oleh sebab itu peneliti ingin melakukan penelitian mengenai 
Rahman, et al/Jurnal Ekonomi Syariah Teori dan Terapan Vol. 6 No. 12 Desember 2019: 2498-2511; KESEJAHTERAAN DALAM PERSPEKTIF MAQASHID SYARIAH PADA KARYAWAN BADAN AMIL ZAKAT DAN LEMBAGA AMIL ZAKAT DI KOTA SURABAYA

"Kesejahteraan Karyawan pada Badan Amil Zakat dan Lembaga Amil Zakat Kota Surabaya." Penelitian ini diharapkan mampu memberi pengetahuan bagi peneliti dan pihak lainnya yang terkait, tentang pentingnya kebijakan yang dilaksanakan oleh pimpinan dalam hal pemenuhan hak dan kewajiban karyawan. Sehingga diharapkan dapat memberikan peningkatan bagi kesejahteraan karyawan dan keluarganya berdasarkan perspektif maqashid syariah

\section{LANDASAN TEORI}

\section{Definisi Karyawan}

Karyawan adalah hal yang utama bagi perusahaan karena kegiatan perusahaan tidak dapat terlaksana tanpa adanya karyawan. Menurut Sinn (2012:112) dalam bukunya yang berjudul Manajemen Syariah: Sebuah Kajian Historis dan Kontemporer menyebutkan bahwa karyawan dalam suatu perusahaan dapat dibagi menjaadi dua jenis, yaitu:

a. Karyawan Tetap

Karyawan tetap merupakan karyawan yang telah memiliki kontrak ataupun perjanjian kerja dengan perusahaan dalam jangka waktu yang tidak ditetapkan (Permanen).

b. Karyawan Tidak tetap (Kontrak)

Karyawan tidak tetap merupakan karyawan yang di pekerjakan ketika perusahaan membutuhkan tenaga kerja tambahan saja. jika kinerjanya jelek dan tidak optimal, karyawan tersebut bisa dipecat.

\section{Pengertian Zakat}

Pasal 1 angka 2 Undang-Undang Nomor 23 Tahun 2011 Tentang Pengelolaan Zakat memberikan pengertian zakat adalah harta yang wajib dikeluarkan oleh seorang muslim atau badan usaha untuk diberikan kepada yang berhak menerimanya sesuai dengan syariat Islam. Sehingga dapat disimpulkan bahwa zakat adalah kewajiban memberikan sebagian harta kita kepada yang berhak sesuai dengan ketentuan syariat Islam yang ada. Dari segi hukum, zakat adalah salah satu rukun Islam yang merupakan wajib atas tiap-tiap orang yang cukup syarat-syaratnya. Ada delapan golongan yang berhak menerima zakat antara lain fakir, miskin, 'amil (pengelola zakat), muallaf (orang yang baru memeluk agama Islam), riqab (budak), gharimin (orang yang memiliki hutang), fii sabilillah (orang yang berjuang di jalan Allah) dan ibnu sabil (orang yang sedang dalam perjalanan jauh).

\section{Pengelolaan Zakat Oleh Badan Amil Zakat dan Lembaga Amil Zakat}

Pengelola Zakat di Indonesia terbagi menjadi dua, yaitu: Badan Amil Zakat (BAZ) dan Lembaga Amil Zakat (LAZ). Pemerintah membentuk Badan Amil Zakat Nasional (BAZNAS) yang merupakan lembaga yang berwenang melakukan tugas pengelolaan zakat secara nasional. Selanjutnya untuk membantu tugas BAZNAS dalam pengelolaan dana zakat, masyarakat dapat membentuk Lembaga Amil Zakat (LAZ). Pembentukan Lembaga 
Rahman, et al/Jurnal Ekonomi Syariah Teori dan Terapan Vol. 6 No. 12 Desember 2019: 2498-2511; KESEJAHTERAAN DALAM PERSPEKTIF MAQASHID SYARIAH PADA KARYAWAN BADAN AMIL ZAKAT DAN LEMBAGA AMIL ZAKAT DI KOTA SURABAYA

Amil Zakat wajib mendapatkan izin dari Menteri atau pejabat yang ditunjuk oleh Menteri, serta adapun salah satu syaratnya yaitu mendapat rekomendasi dari BAZNAS. Secara umum, lembaga pengelola zakat memiliki dua fungsi, yakni (Ridwan, 2005):

1) Sebagai Perantara Keuangan

Amil Zakat memiliki peran sebagai penghubung antara pihak muzakki dengan mustahik. Sebagai perantara keuangan, amil dituntut menjalankan asas trust (kepercayaan). Selayaknya lembaga keuangan yang lain, asas kepercayaan menjadi syarat mutlak yang harus dijalankan. Setiap amil dituntut mampu menginterpretasikan keunggulannya sampai terlihat jelas positioning organisasi, sehingga masyarakat dapat memberikan kepercayaan mereka pada amil tersebut.

2) Pemberdayaan

Fungsi ini merupakan upaya untuk mewujudkan misi pembentukan amil, yakni bagaimana muzakki menjadi lebih berkah rezekinya dan ketentraman hidupnya menjadi terjamin, dan disamping itu para mustahik tidak selamanya bergantung pada pemberian dana ZIS (Zakat, Infaq, Shadaqah) diharapkan dalam jangka yang panjang mustahik tersebut dapat meningkat taraf hidupnya dan menjadi seorang muzakki.

\section{Amil Zakat}

Menurut Huda (2015:301), pengertian dari amil zakat atau pengumpul zakat adalah mereka yang diangkat oleh pihak yang berwenang yang diberikan tugas untuk melaksanakan berbagai kegiatan yang berkaitan dengan urusan zakat. Termasuk dalam hal ini adalah mengumpulkan dana zakat serta membagikannya kepada para mustahik penerima dana zakat. Pihak yang ditunjukkan sebagai amil zakat diharapkan sebagai pihak yang tidak perlu diragukan lagi kejujurannya, karena dana zakat yang menjadi bagian dari amil tidak boleh langsung diambil oleh para petugas amil, akan tetapi harus mendapatkan persetujuan dari atasan para petugas amil tersebut. Tugas utama para amil dalam menyalurkan zakat adalah:

1. Menarik zakat dari para muzakki

2. Mendoakan ketika muzakki menyerahkan zakatnya

3. Mencatat zakat dengan benar (yang diserahkan oleh muzakki)

4. Mengatur pembagian zakat dengan benar dan adil

5. Menyalurkan zakat kepada yang berhak menerimanya

\section{Badan Amil Zakat dan Lembaga Amil Zakat}

Menurut Undang- Undang Nomor 23 Tahun 2011 tentang pengelolaan zakat, pengelolaan zakat dilakukan oleh badan yang dibentuk pemerintah (BAZNAS) dan lembaga yang didirikan oleh masyarakat 
Rahman, et al/Jurnal Ekonomi Syariah Teori dan Terapan Vol. 6 No. 12 Desember 2019: 2498-2511; KESEJAHTERAAN DALAM PERSPEKTIF MAQASHID SYARIAH PADA KARYAWAN BADAN AMIL ZAKAT DAN LEMBAGA AMIL ZAKAT DI KOTA SURABAYA

(LAZ). Dengan lahirnya undang-undang ini, pemerintah dalam hal ini Departemen Agama melakukan berbagai upaya dalam rangka memberikan dorongan dan fasilitas agar pengelolaan zakat yang dilakukan Badan Amil Zakat Nasional (BAZNAS) dan Lembaga Amil Zakat (LAZ) dapat berjalan secara profesional, amanah, dan transparan, sehingga tujuan pengelolaan zakat bagi kemaslahatan dan kemakmuran umat dapat tercapai.

\section{Konsep Kesejahteraan}

Menurut Undang-Undang Nomor 13 Tahun 2003 Tentang Ketenagakerjaan dalam Pasal 1 angka 31 yang berbunyi: Kesejahteraan pekerja/buruh adalah suatu pemenuhan kebutuhan dan/atau keperluan yang bersifat jasmaniah dan rohaniah, baik di dalam maupun di luar hubungan kerja, yang secara langsung atau tidak langsung dapat mempertinggi produktivitas kerja dalam lingkungan kerja yang aman dan sehat. Maka dari itu dapat disimpulkan bahwa dengan terjaminnya segala hak-hak dari para buruh atau karyawan dalam suatu perusahaan, dapat meningkatkan kinerja dan performa karyawan dalam menyelesaikan setiap tugas-tugasnya dengan baik dan optimal. Hak-hak yang yang dimaksud yaitu seperti yang terdapat pada Pasal 99 ayat 1 UndangUndang Nomor 13 Tahun 2003 Tentang Ketenagakerjaan yaitu, setiap pekerja/buruh dan keluarganya berhak untuk memperoleh jaminan sosial tenaga kerja. Selain itu, untuk meningkatkan kesejahteraan bagi pekerja/buruh dan keluarganya, pengusaha/perusahaan wajib menyediakan fasilitas kesejahteraan. Pengadaan fasilitas kesejahteraan tersebut dilaksanakan dengan memperhatikan kebutuhan pekerja/buruh dan ukuran kemampuan perusahaan (Undang-Undang Nomor 13 Tahun 2003 Tentang Ketenagakerjaan Pasal 100 ayat 1 dan 2).

Kesejahteraan menurut Al-Ghazali adalah tercapainya kemaslahatan. Kemaslahatan sendiri merupakan terpeliharanya tujuan syara' (maqashid alshari'ah). Manusia tidak dapat merasakan kebahagiaan dan kedamaian batin melainkan setelah tercapainya kesejahteraan yang sebenarnya dari seluruh umat manusia di dunia melalui pemenuhan kebutuhan-kebutuhan rohani dan materi. Untuk tercapainya tujuan syara' seperti yang telah disebutkan diatas, maka Al-Ghazali menjabarkan tentang sumber-sumber kesejahteraan, yaitu: terpeliharanya agama, jiwa, akal, keturunan, dan harta. (Abdur Rohman, 2010:84-86).

\section{Maqashid Syariah}

Maqashid Syariah dibagi menjadi tiga tingkatan pembagian ini berkaitan dengan usaha menjaga kelima unsur pokok kehidupan dalam usaha mencari tujuan persyariatan hukum utama yaitu untuk mewujudkan kemaslahatan manusia. (Shidiq, 2009). Ketiga tingkatan dalam maqashid syariah tersebut dalam jurnal Shidiq dijelaskan sebagai berikut: 
Rahman, et al/Jurnal Ekonomi Syariah Teori dan Terapan Vol. 6 No. 12 Desember 2019: 2498-2511; KESEJAHTERAAN DALAM PERSPEKTIF MAQASHID SYARIAH PADA KARYAWAN BADAN AMIL ZAKAT DAN LEMBAGA AMIL ZAKAT DI KOTA SURABAYA

1. Al-Daruriyyat (Tujuan Primer)

Tujuan primer harus ada dalam kehidupan manusia, jika tidak tercapai akan berakibat fatal Karena dapat merusak kehidupan itu sendiri dan tidak adanya kemaslahatan di dunia maupun akhirat.

2. Al-Hajiyyat (Tujuan Sekunder)

Tujuan sekunder diperlukan manusia untuk mempermudah dalam kehidupan dan menghilangkan kesulitan. Jika tidak dicapai akan terjadi kesulitan dan implikasinya tidak sampai merusak kehidupan.

3. At-Tahsiniyyah (Tujuan Tersier)

Tujuan tersier merupakan tuntutan moral yang artinya itu untuk kebaikan dan kemuliaan. Jika tidak dapat dicapai, maka tidak akan merusak ataupun menyulitkan kehidupan manusia.

Begitu pula dengan Al Imam alSyathibi yang mengeluarkan pendapat bahwa tujuan terbagi menjadi dua, yaitu maksud Tuhan membuat syariah dan maksud dari mukallaf yang berarti manusia dianjurkan hidup dalam kemaslahatan di dunia maupun di akhirat. Maqashid syariah sendiri terbagi menjadi lima jenis yaitu sebagai berikut :

a) Memelihara Agama

Agama Islam menjaga hak dan kebebasan, kebebasan yang pertama adalah kebebasan berkeyakinan dan beribadah. Setiap orang berhak menentukan keyakinannya dan tidak boleh dipaksa masuk ke agama lain juga tidak boleh ditekan untuk masuk ke agama islam. Hal ini sebagaimana yang tercantum dalam Al Quran surat Al- Baqarah ayat 256 :

lā ikrāha fid-dīn, qat tabayyanar-rusydu minal-gayy, fa may yakfur biț-tāgụti wa yu'mim billāhi fa qadistamsaka bil'urwatil-wuśqā lanfișāma lahā, wallāhu samīun 'alim

Artinya: Tidak ada paksaan untuk (memasuki) agama (Islam); sesungguhnya telah jelas jalan yang benar daripada jalan yang sesat. Karena itu barangsiapa yang ingkar kepada Thaghut dan beriman kepada

Allah, maka sesungguhnya ia telah berpegang kepada buhul tali yang amat kuat yang tidak akan putus. Dan Allah Maha Mendengar lagi Maha Mengetahui. (Depag RI dan Terjemahannya, 2000).

b) Memelihara Jiwa

Syariat Islam menjaga jiwa dengan pemeliharaan yang tak terbatas agar terhindar dari tindakan yang merusak misalnya pembunuhan dan penganiayaan. Disyariatkannya hukum-hukum adalah untuk kemaslahatan jiwa serta dan menolak hal-hal yang dapat merusak jiwa. Jiwa yang dijaga oleh syariat adalah jiwa yang dipelihara karena sebab Islam, jizyah atau (perjanjian) keamanan. Sedangkan seperti ahlu al-harbi (orang yang memerangi/ berperang melawan Islam) tidak temasuk dalam penjagaan ini. 
Rahman, et al/Jurnal Ekonomi Syariah Teori dan Terapan Vol. 6 No. 12 Desember 2019: 2498-2511; KESEJAHTERAAN DALAM PERSPEKTIF MAQASHID SYARIAH PADA KARYAWAN BADAN AMIL ZAKAT DAN LEMBAGA AMIL ZAKAT DI KOTA SURABAYA

c) Memelihara akal

Anjuran untuk memelihara akal dapat dilakukan dengan menuntut ilmu pengetahuan. Jika tidak dilakukan tidak akan mengancam jiwa tapi akan mempersulit manusia dalam hal pegembangan diri (Cahyani, 2014).

d) Memelihara keturunan

Perlindungan Islam dalam memelihara keturunannya dapat terlihat dengan disyariatkannya pernikahan dan mengharamkan zina. Selanjutnya ditetapkan cara perkawinan dan syarat-syarat yang harus dipenuhi. Selain itu juga ditetapkannya orang yang dilarang atau tidak boleh dikawini. Hal tersebut bertujuan agar perkawinan sah dan keturunan yang dihasilkan dari perkawinan tersebut sah berasal dari keturuanan ayahnya.

e) Memelihara harta

Harta merupakan salah satu kebutuhan inti bagi umat manusia untuk mempertahankan kelangsungan hidupnya, dan manusia tidak bisa terlepas dari penggunaan harta tersebut. Manusia berusaha mencari harta demi menjaga eksistensi hidupnya dan juga menjadi salah satu upaya untuk menambah ketaqwaan kepada Allah SWT. Tetapi adapun ketentuan dalam hal memperoleh harta tersebut, pertama, harta yang diperoleh harus didapatkan dengan cara yang halal, kedua, harta tersebut digunakan semata-mata hanya untuk berbuat kebaikan, ketiga, dari harta yang diperoleh tadi seseorang tersebut juga harus mengamalkan harta tersebut.

\section{METODE PENELITIAN}

\section{Pendekatan penelitian}

Pendekatan penelitian yang digunakan dalam penelitian ini adalah pendekatan kualitatif. Metode penelitian kualitatif adalah metode penelitian yang digunakan untuk meneliti pada kondisi obyek yang alamiah, dimana peneliti berperan sebagai instrumen kunci, teknik pengumpulan data dilakukan secara triangulasi, analisis data bersifat induktif, dan hasil penelitian kualitatif lebih menekankan makna dari pada generalisasi (Sugiyono, 2014:1). Metode yang digunakan dalam penelitian ini yaitu metode studi kasus. Studi kasus adalah suatu inkuiri empiris yang memiliki peran untuk: menyelidiki fenomena di dalam konteks kehidupan nyata, yang dapat memberikan batasan antara fenomena dan konteks yang tak tampak dengan tegas, dan hal itu dapat menjadi multisumber bukti yang dapat dimanfaatkan (Yin, 2015:18).

Menurut Yin (2015:1), studi kasus merupakan strategi yang cocok untuk jenis pertanyaan "how" atau "why", selain itu peneliti memiliki sedikit peluang untuk mengendalikan peristiwa yang akan diteliti, dan fokus penelitiannya terletak pada fenomena kontemporer (masa kini) di dalam konteks kehidupan nyata (Yin, 2015:1). Penelitian studi kasus tidak hanya menjawab pertanyaan mengenai 'apa' 
Rahman, et al/Jurnal Ekonomi Syariah Teori dan Terapan Vol. 6 No. 12 Desember 2019: 2498-2511; KESEJAHTERAAN DALAM PERSPEKTIF MAQASHID SYARIAH PADA KARYAWAN BADAN AMIL ZAKAT DAN LEMBAGA AMIL ZAKAT DI KOTA SURABAYA

(what) obyek yang diteliti, tetapi lebih menyeluruh dan mendalam lagi, yaitu tentang 'bagaimana' (how) atau 'mengapa' (why). Kedua pertanyaan tersebut langsung mengarah ke serangkaian peristiwa kontemporer (masa kini), sehingga peneliti hanya memiliki peluang kecil atau tidak memiliki peluang sama sekali untuk melakukan kontrol terhadap peristiwa yang terjadi. Dalam penelitian ini akan menjawab rumusan masalah yaitu bagaimana kesejahteraan karyawan Badan Amil Zakat dan Lembaga Amil Zakat kota Surabaya jika ditinjau melalui perspektif maqashid shariah.

Dalam penelitian ini, desain penelitian studi kasus yang dipilih yaitu desain studi kasus tunggal, karena hanya memiliki satu kasus yaitu tentang kesejahteraan karyawan.

\section{Jenis dan Sumber data}

Data yang dihimpun dalam penelitian ini menggunakan data primer berupa hasil wawancara dari beberapa narasumber dan data sekunder berupa laporan atau website lembaga amil zakat kota Surabaya. Sumber dan jenis data dalam penelitian ini diperoleh dengan cara berikut:

a. Data Primer

Data primer didapatkan melalui wawancara dengan para karyawan di beberapa lembaga amil zakat yang ada di Surabaya. Key informan dalam penelitian ini adalah manajer bagian SDM dari badan amil zakat dan lembaga amil zakat yang ada di Surabaya. Sedangkan informannya adalah karyawan dari masing-masing divisi yang ada di badan amil zakat dan lembaga amil zakat tersebut, dengan meminta pertimbangan atau saran dari manajer bagian SDM yang bertindak sebagai key informan.

b. Data Sekunder

Data sekunder merupakan data yang digunakan untuk mendukung suatu penelitian, yang didapatkan secara tidak langsung dari suatu objek penelitian yang berupa arsip, laporan, dan dokumen yang relevan serta kajian pustaka yang berkaitan dengan penelitian. Data sekunder dalam penelitian ini berasal dari berbagai literatur seperti buku, jurnal, artikel, dan skripsi yang berkaitan dengan kesejahteraan karyawan, hak-hak dan kewajiban karyawan dan peraturan terkait ketenagakerjaan.

\section{Lokasi Penelitian dan Unit Analisis}

Lokasi penelitian adalah tempat dimana penelitian akan dilakukan. Dalam penelitian ini, peneliti mengambil objek penelitian di badan amil zakat dan lembaga amil zakat yang ada di Kota Surabaya, yaitu:

1. Badan Amil Zakat Nasional Jawa Timur, Jalan Raya Dukuh Kupang 122-124, Kel.Dukuh Pakis, Kec. Dukuh Kupang Kota Surabaya

2. Lembaga Amil Zakat Yatim Mandiri Surabaya, Jalan Raya Jambangan No.135, Surabaya 
Rahman, et al/Jurnal Ekonomi Syariah Teori dan Terapan Vol. 6 No. 12 Desember 2019: 2498-2511; KESEJAHTERAAN DALAM PERSPEKTIF MAQASHID SYARIAH PADA KARYAWAN BADAN AMIL ZAKAT DAN LEMBAGA AMIL ZAKAT DI KOTA SURABAYA

3. Lembaga Amil Zakat Yayasan Dana Sosial Al-Falah Surabaya, Jl. Kertajaya $8 \mathrm{C} / 17$

4. Lembaga Amil Zakat Nurul Falah Surabaya, Jl. Ketintang Timur PTT Gang V-B, Ketintang, Gayungan, Kota Surabaya, Jawa Timur 60242

Unit analisis dalam suatu penelitian yaitu sesuatu yang berkaitan dengan komponen yang akan diteliti. Unit analisis suatu penelitian dapat berupa individu, kelompok, organisasi, benda, dan waktu tertentu sesuai dengan permasalahannya. Unit analisis dalam penelitian ini berupa individu, yaitu manajer dan karyawan yang ada di badan amil zakat dan lembaga amil zakat.

\section{Prosedur pengumpulan data}

Pengumpulan data pada
penelitian studi kasus dapat
menggunakan enam sumber, yaitu
dokumen, rekaman arsip, wawancara, observasi langsung, observasi pemeran serta, dan perangkat fisik (Yin, 2015:103). Penelitian ini menggunakan teknik pengumpulan data sebagai berikut :

a) Wawancara

Penelitian ini menggunakan metode wawancara terstruktur di mana peneliti telah menyiapkan pertanyaanpertanyaan mengenai topik yang akan diteliti secara tertulis. Dalam penelitian ini, teknik pengambilan informan yang digunakan yaitu teknik purposive sampling. Menurut Sugiyono (2014:122) pengertian purposive sampling adalah teknik pengambilan sampel sumber data dengan pertimbangan tertentu.

b) Dokumen

Dokumen memiliki peran penting dalam pengumpulan data pada penelitian studi kasus karena dapat menambah data untuk mendukung informasi yang ada. Bentuk dokumen yang digunakan dalam penelitian ini yaitu: penelitian terdahulu berupa jurnal ilmiah dan artikel berita.

c) Observasi langsung Pada penelitian ini, observasi bertujuan untuk mengamati implementasi kebijakan lembaga amil zakat dalam rangka meningkatkan kesejahteraan karyawannya, dengan menggunakan acuan prinsip maqashid syariah. Sehingga nantinya dapat diketahui apakah kesejahteraan karyawan di badan amil zakat lembaga amil zakat sudah tercukupi atau belum.

\section{Teknik Analisis}

Teknik analisis data yang digunakan dalam penelitian ini yaitu teknik analisis kurang dominan dengan menggunakan pendektan studi kasus berupa analisis deskriptif dengan menggunakan metode analisis data dan mendeskripsikan hasil observasi wawancara. Penelitian ini menggunakan teknik analisis kualitatif deskriptif, dengan mencocokkan suatu teori dengan kajian proposisi yang ditemukan. Tujuan dilakukan tersebut adalah menganalisis studi kasus dengan membuat penjelasan dan menggambarkan kasus tersebut serta 
Rahman, et al/Jurnal Ekonomi Syariah Teori dan Terapan Vol. 6 No. 12 Desember 2019: 2498-2511; KESEJAHTERAAN DALAM PERSPEKTIF MAQASHID SYARIAH PADA KARYAWAN BADAN AMIL ZAKAT DAN LEMBAGA AMIL ZAKAT DI KOTA SURABAYA

membuktikan proposisi teori yang telah dibuat. Penelitian dilakukan dengan cara membahas implementasi kebijakan perusahaan dalam meningkatkan kesejahteraan karyawan.

Penelitian ini akan melihat melalui perspektif kesejahteraan yang terdapat dalam maqashid syariah, lima hal yang harus diupayakan dan dijaga kemaslahatannya melaui tingkatan kebutuhan dharuriyyat, hajiyyat dan tahsiniyyat. Kelima maqashid syariah tersebut mencakup memelihara agama (ad-din), memelihara jiwa (an-nafs), memelihara akal (al-'aql), memelihara keturunan (an-nasl), dan memelihara harta (al-Mal).

Dalam metodologi penelitian kualitatif, menurut Patton ada empat kriteria yang berhubungan dengan keabsahan data yaitu triangulasi data, triangulasi pengamat, triangulasi teori, triangulasi metode. Penelitian ini akan menggunakan beberapa teknik keabsahan data sebagai berikut (Afifudin dan Saebani, 2012:143):

a. Triangulasi data

Menggunakan berbagai sumber data dengan cara menggali sumber dan mengecek baik derajat kepercayaan suatu data yang telah diperoleh melalui beberapa sumber, seperti dokumen, arsip, hasil wawancara, hasil oberservasi atau juga dengan mewawancarai lebih dari satu subjek yang dianggap memiliki sudut pandang yang berbeda. Dari metode ini penulis akan membandingkan keselarasan antara wawancara dengan pihak yang terkait yaitu karyawan lembaga amil zakat dengan kebijakan perusahaan terkait kesejahteraan karyawan.

b. Triangulasi metode

Metode ini dilakukan dengan membandingkan informasi atau data dengan cara yang berbeda. Untuk memperoleh kebenaran informasi yang handal dan gambaran yang utuh mengenai informasi tertentu, peneliti bisa menggunakan metode wawancara bebas dan wawancara terstruktur. atau peneliti menggunakan metode wawancara dan observasi atau pengamatan untuk mengecek kebenaran.

\section{HASIL DAN PEMBAHASAN}

\section{Konsep Kesejahteraan}

Konsep kesejahteraan yang diungkapkan dari masing-masing informan berbeda antara yang satu dengan yang lainnya. Misalnya seperti yang diungkapkan oleh Informan 1 yaitu Bapak Mahrus selaku karyawan BAZNAS Jatim yaitu:

"Kesejahteraan adalah suatu nikmat Allah yang diberikan kepada hambanya dalam rangka untuk mensyukuri segala pemberiannya, sehingga berapapun hasil yang yang didapat, harus tetap bersyukur agar selalu mendapatkan kesehatan, dan keberkahan."

Dari pernyataan tersebut dapat dijelaskan bahwa kesejahteraan merupakan sesuatu 
Rahman, et al/Jurnal Ekonomi Syariah Teori dan Terapan Vol. 6 No. 12 Desember 2019: 2498-2511; KESEJAHTERAAN DALAM PERSPEKTIF MAQASHID SYARIAH PADA KARYAWAN BADAN AMIL ZAKAT DAN LEMBAGA AMIL ZAKAT DI KOTA SURABAYA

pemberian Allah yang harus kita syukuri berapapun hasil yang diterima. Gaji atau pendapatan yang diterima oleh karyawan yang bekerja pada Badan Amil Zakat dan Lembaga Amil Zakat memang tergolong kecil dan jauh dari standart UMR, tetapi mereka merasa bahwa dari pendapatan yang mereka terima, mereka dapat memenuhi kebutuhan hidup mereka.

\section{Konsep Maqashid Syariah}

\section{Memelihara Agama}

Seluruh informan di masing-masing lembaga menyatakan tidak ada batasan dalam melaksanaan ibadah, malah dianjurkan untuk mengerjakan ibadah dengan sebaik mungkin. Terdapat fasilitas tempat ibadah yang sudah layak digunakan untuk beribadah, adapun ketentuan untuk karyawan laki-laki dianjurkan melaksanakan sholat berjamaah di masjid, dan untuk karyawan wanita melaksanakan sholat di musholla yang terdapat di masing-masing lembaga. Setiap pagi sebelum memulai aktivitas, disetiap lembaga melaksanakan rutinitas doa pagi dan mengaji bersama, selain itu ada juga kajiankajian yang dapat meningkatkan keimanan karyawan. Adapun pelayanan pembayaran zakat yang sudah diterapkan untuk setiap karyawan di masing-masing lembaga guna untuk menyempurnakan ibadah bagi setiap karyawan, pembayaran zakat tersebut ada yang sistem potong gaji dan ada sistem manual.

\section{Memelihara Jiwa}

Dalam hal pemeliharaan jiwa, baik di Badan Amil Zakat dan Lembaga Amil Zakat sudah memberikan fasilitas BPJS Kesehatan dan Ketenagakrerjaan bagi setiap karyawannya, dengan aturan dan syarat tertentu yang tentu berbeda antara satu lembaga dengan lembaga yang lain. Terdapat tambahan kompensasi bagi karyawan dan kelvarga karyawan baik yang sakit, melahirkan, dan bila ada karyawan atau keluarga inti karyawan yang meninggal. Pemberian kompensasi biasanya diberikan dalam bentuk uang santunan dari masingmasing lembaga ataupun uang yang dikumpulkan dari tiap-tiap karyawan. Adapun manfaat dari pemberian kompensasi ini guna untuk mempererat tali persaudaraan antar sesama karyawan.

\section{Memelihara akal}

Terdapat pelatihan untuk meningkatkan skill karyawan yang disesuaikan dengan kebutuhan di masing-masing divisi. Dalam pelaksanaan pelatihan tersebut para peserta pelatihan diberikan fasilitas seperti pemberian uang transport, serta akomodasi apabila pelatihan tersebut dilaksanakan di luar kota. Dalam pemberian beasiswa bagi karyawan, tidak semua lembaga memberikan beasiswa bagi karyawannya. 
Rahman, et al/Jurnal Ekonomi Syariah Teori dan Terapan Vol. 6 No. 12 Desember 2019: 2498-2511; KESEJAHTERAAN DALAM PERSPEKTIF MAQASHID SYARIAH PADA KARYAWAN BADAN AMIL ZAKAT DAN LEMBAGA AMIL ZAKAT DI KOTA SURABAYA

\section{Memelihara keturunan}

Dengan bekerja di Badan Amil Zakat dan Lembaga Amil Zakat secara tidak langsung seluruh karyawan mengutamakan untuk memberikan pendidikan agama, baik secara formal, maupun informal. Pendidikan secara formal yaitu dengan menyekolahkan anaknya ke sekolah berbasis Islam, ataupun pondok pesantren. Bagi karyawan wanita, terdapat cuti untuk melahirkan dengan ketentuan waktu 23 bulan.

\section{Memelihara harta}

Terdapat tambahan kompensasi dan insentif selain gaji yang diberikan kepada karyawan, salah satu bentuk kompensasi atau insentif tersebut berupa THR (Tunjangan Hari Raya), insentif kehadiran apabila datang tepat waktu dan jarang absen, dan insentif apabila karyawan tersebut dapat mengajak donatur baru untuk berdonasi. Reward untuk karyawan berprestasi belum diterapkan di semua lembaga. Dalam hal mengatur pengeluaran, seluruh karyawan berpendapat bahwa mendahulukan untuk kebutuhan yang bersifat primer terlebih dahulu, seperti untuk membayar sekolah anak, untuk pemenuhan kebutuhan sehari-hari, dan untuk membayar cicilan-cicilan.

\section{v. Kesimpulan dan saran}

Berdasarkan hasil pembahasan pada bab empat, maka kesimpulan dari penelitian mengenai Kesejahteraan dalam Perspektif Maqashid Syariah pada karyawan Badan Amil Zakat dan Lembaga Amil Zakat di Kota Surabaya adalah sebagai berikut:

1. Indikator Kesejahteraan dapat dikatakan sudah sejahtera, karena ukuran kesejahteraan menurut masingmasing karyawan bukanlah sematamata vang saja, tetapi nilai atau value keislaman dan ketaqwaan kepada Allah SWT yang menjadi faktor utama. Jika dilihat dari segi gaji/pendapatan yang diterima oleh karyawan Badan Amil Zakat dan Lembaga Amil Zakat sudah tergolong cukup untuk memenuhi kebutuhan mereka. Karena bagi karyawan yang utama adalah mencari ridho Allah SWT, jadi bukan untuk memenuhi kebutuhan duniawi saja.

2. Indikator maqashid Syariah

a) Dari segi Memelihara Agama, di Badan Amil Zakat dan Lembaga Amil Zakat dapat diketahui bahwa para karyawan sudah dapat memenuhi kebutuhan agama mereka karena adanya faktor tidak adanya batasan dalam melaksanakan ibadah, sehingga mereka bisa lebih fleksibel dalam mengerjakan ibadah mereka, dalam pelaksanaan ibadah juga didukung dengan fasilitas tempat ibadah yang sangat layak digunakan untuk beribadah. Lalu adanya kajian atau pengajian rutin yang dilaksanakan di masing- 
Rahman, et al/Jurnal Ekonomi Syariah Teori dan Terapan Vol. 6 No. 12 Desember 2019: 2498-2511; KESEJAHTERAAN DALAM PERSPEKTIF MAQASHID SYARIAH PADA KARYAWAN BADAN AMIL ZAKAT DAN LEMBAGA AMIL ZAKAT DI KOTA SURABAYA

masing lembaga guna meningkatkan keimanan karyawan.

b) Dari segi memelihara Jiwa, karyawan sudah diberikan fasilitas BPJS Kesehatan atau Ketenagakerjaan sebagai bentuk perlindungaan jiwa mereka, selain itu jika ada karyawan yang sakit, maka karyawan-karyawan yang lain akan mengumpulkan vang santunan secara sukarela dimana hal ini dapat menjadi salah satu cara untuk memperkuat tali persaudaraan diantara sesama karyawan Badan Amil Zakat dan Lembaga Amil Zakat.

c) Dari segi Akal, untuk pelatihan yang dilakukan di Badan Amil Zakat dan Lembaga Amil Zakat sudah cukup sering dilakukan guna untuk meningkatkan skill karyawan yang nantinya juga dapat berpengaruh secara langsung bagi kemajuan Badan Amil Zakat dan Lembaga Amil Zakat.

d) Dari Segi keturunan, secara tidak langsung karyawan yang bekerja di Badan Amil Zakat dan Lembaga Amil Zakat berupaya untuk mengutamakan pendidikan agama, dengan cara memberikan pendidikan berbasis Islam, dengan cara menyekolahkan ke sekolah Islam atau ke pondok pesantren. Bagi karyawan wanita, terdapat cuti hamil dengan kurun waktu kurang lebih 3 bulan. e) Dari segi Harta, karyawan BAZ dan LAZ mendapatkan kompensasi/insentif lain jika ada tugas/dinas luar, insentif jika datang tepat waktu, Tunjangan Hari Raya, dan insentif jika dapat mengajak donatur baru untuk berdonasi. Untuk cara bagaimana mengatur pengeluaran setiap bulan, masingmasing karyawan menyatakan bahwa mereka mendahulukan untuk pemenuhan kebutuhan primer (pokok) terlebih dahulu, daripada kebutuhan sekunder. Misalnya, menyisihkan vang dari pendapatan yang diterima untuk keperluan sekolah anak, kebutuhan sehari-hari, dan keperluan cicilan-cicilan.

\section{Saran}

1. Pemberian fasilitas pengembangan keilmuan berupa pemberian beasiswa untuk meningkatkan jenjang pendidikan bagi karyawan hendaknya berlaku untuk semua Lembaga Amil Zakat, agar nantinya ilmu yang didapat dari studi tersebut bisa memberikan manfaat yang lebih baik lagi untuk lembaganya.

2. Pemberian kompensasi / insentif lainnya untuk karyawan yang berprestasi seharusnya diterapkan di semua Lembaga Amil Zakat, karena dapat menjadi salah satu upaya untuk memotivasi dan meningkatkan kinerja karyawan agar dapat memberikan effort lebih untuk lembaga. 
Rahman, et al/Jurnal Ekonomi Syariah Teori dan Terapan Vol. 6 No. 12 Desember 2019: 2498-2511; KESEJAHTERAAN DALAM PERSPEKTIF MAQASHID SYARIAH PADA KARYAWAN BADAN AMIL ZAKAT DAN LEMBAGA AMIL ZAKAT DI KOTA SURABAYA

3. Untuk penelitian selanjutnya bisa membahas lebih dalam lagi mengenai aspek maqashid syariahnya.

\section{DAFTAR PUSTAKA}

Afifudin dan Beni Ahmad Saebani. 2012. Metodologi Penelitian Kualitatif. Bandung: Pustaka Setia.

Badan Pusat Statistik, 2016/2017. Indikator Kesejahteraan Rakyat Provinsi Jawa Timur 2016/2017.

Cahyani, Intan. 2014. Teori dan Aplikasi Maqashid Syariah. Jurnal Al-Qadau Vol 1 Nomor 2.

Chapra, Umer. 2001. Islam dan Tantangan Ekonomi. Jakarta: Gema Insani Press

Departemen Pendidikan dan Kebudayaan. 1999. Kamus Besar Bahasa Indonesia. Jakarta: Balai Pustaka

Enggardini, Rohma Vihana. 2016. "Kesejahteraan Karyawan Perspektif Maqashid Syariah Pada Pusat Penelitian Kopi Dan Kakao Indonesia". Skripsi. Universitas Airlangga.
Fahrudin, Adi. 2012. Pengantar Kesejahteraan Sosial. Bandung: Refika Aditama

Filasufah, January. 2011. "Analisis Etos Kerja Pedagang Muslim Di Sekitar Makam Kadilangu (Sunan Kalijaga) Demak Serta Dampaknya Terhadap Peningkatan Kesejahteraan. Skripsi. Institut Agama Islam Negeri Walisongo.

Hakim, Lukman. 2012. Prinsip-Prinsip Ekonomi Islam. Surakarta: Erlangga.

Karim, Adiwarman. 2016. Sejarah Pemikiran Ekonomi Islam. Jakarta: PT RajaGrafindo Persada.

Kasri, Rahmatina A. 2016. Maqasid alShariah and Performance of Zakah Institutions. Jurnal Kyoto Bulletin of Islamic Area Studies Maret 2016 hal 19-41.

Purwana, Agung Eko. 2014. Kesejahteraan Dalam Perspektif Ekonomi Islam. Jurnal Justitia Islamica Vol. 11 No. 1 Januari-Juni 2014 hal 21-42. 